\title{
Pencemaran Udara Akibat Gas Buang Kendaraan Bermotor Dan Dampaknya Terhadap Kesehatan
}

\author{
Haruna $^{1}$, Lahming ${ }^{2}$, Faizal Amir ${ }^{3}$, Ahmad Rifqi Asrib ${ }^{3}$ \\ ${ }^{1}$ Program Studi Pendidikan Teknik Otomotif, Fakultas Teknik, Universitas Negeri Makassar \\ *Email: haruna@unm.ac.id \\ ${ }^{2}$ Program Studi Pendidikan Teknologi Pertanian, Fakultas Teknik, Universitas Negeri Makassar \\ ${ }^{3}$ Program Studi Pendidikan Teknik Sipil, Fakultas Teknik, Universitas Negeri Makassar
}

@ 2019 - UEJ Program Studi Pendidikan Kependudukan dan Lingkungan Hidup Universitas Negeri Makassar. Ini adalah artikel dengan akses terbuka dibawah Licensi CC BY-NC-4.0 (https://creativecommons.org/licenses/by-nc/4.0/ )

\begin{abstract}
This study aims: to describe the composition and behavior of exhaust gases of motorized vehicles that can have an impact on human health. Based on the results of a theoretical study of various information that the main pollutants in motor vehicle exhaust gases are carbon monoxide (CO), hindrocarbon compounds, nitrogen oxides (NOx) and sulfur (SOx), and dust particulates including lead (PB). Chemical reactions in the atmosphere sometimes take place in a long and complex reaction chain, and produce an end product that can be more active or weaker than the original compound. Motor vehicle exhaust gases which have an impact on health are classified as follows; (1). Pollutants which mainly interfere with the respiratory tract. Included in this group are sulfur oxides, particulates, nitrogen oxides, ozone and other oxides, (2). Pollutants that cause systemic poisons, such as monoxide and lead / lead hydrocarbons, (3). Pollutants suspected of causing cancer such as hydrocarbons, (4). Conditions that interfere with comfort such as noise, street dust, etc. So the conclusion is that in anticipating the negative impacts caused by motor vehicle exhaust gases, the role of the government in setting several regulations and policies in the environmental field is needed, where every business or activity is prohibited from violating the quality standards and standard criteria of environmental damage set by government.
\end{abstract}

Keywords: Management, Community Forestry, Ecological insight, Sustainable economy

ABSTRAK. Penelitian ini bertujuan: menguraikan tentang komposisi dan perilaku gas buangan kendaraan bermotor yang dapat berdampak pada kesehatan manusia.

Berdasarkan hasil kajian teori dari berbagai informasi bahwa bahan pencemar yang utama didalam gas buangan kendaraan bermotor adalah karbon monoksida (CO), senyawa hindrokarbon, oksida nitrogen (NOx) dan sulfur (SOx), dan partikulat debu termasuk timbel (PB). Reaksi kimia di atmosfer kadangkala berlangsung dalam suatu rantai reaksi yang panjang dan rumit, dan menghasilkan produk akhir yang dapat lebih aktif atau lebih lemah dibandingkan senyawa aslinya. Gas buang kendaraan bermotor yang berdampak pada kesehatan digolongkan sebagai berikut; (1). Bahanbahan pencemar yang terutama mengganggu saluran pernafasan. Yang termasuk dalam golongan ini adalah oksida sulfur, partikulat, oksida nitrogen, ozon dan oksida lainnya, (2). Bahan-bahan pencemar yang menimbulkan pengaruh racun sistemik, seperti hidrokarbon monoksida dan timbel/timah hitam, (3).Bahan-bahan pencemar yang dicurigai menimbulkan kanker seperti hidrokarbon, (4). Kondisi yang mengganggu kenyamanan seperti kebisingan, debu jalanan, dll. Sehingga kesimpulannya bahwa dalam mengantisipasi dampak negatif yang ditimbulkan oleh gas buangan kendaraan bermotor, maka peran pemerintah dalam menetapkan beberapa peraturan dan kebijaksanaan di bidang lingkungan hidup sangat dibutuhkan, dimana setiap usaha atau kegiatan dilarang melanggar baku mutu dan kriteria baku kerusakan lingkungan hidup yang telah ditetapkan oleh pemerintah.

Kata Kunci: exhaust gas, motor vehicles, air pollution, health 
UNM Environmental Journals, vol. 2 No. 2 April hal. 57-61

\section{PENDAHULUAN}

Aktivitas manusia pada dasarnya adalah sebuah proses pengubahan zat atau energi dari suatu bentuk ke bentuk lainnya. Setiap proses tersebut tidak didapat sepenuhnya mampu diubah, melainkan selalu ada sisa atau disebut entropy yang kemudian menjadi sampah atau limbah yang masuk atau dimasukkan ke lingkungan, sampah atau limbah ini kemudian akan menurunkan kualitas lingkungan jika tidak dikelola dengan baik (Dermawan, 2018; Maulida, 2017). Sisa atau entropy berbagai kegiatan manusia tersebut ada yang dibuang ke wilayah-wilayah perairan, ke permukaan tanah dan ke udara. Sehingga pencemaran dapat dibedakan menjadi pencemaran air, udara dan tanah.

Berdasarkan Undang-Undang Nomor 32 tahun 2009 pasal 1 ayat 12 mengenai Pencemaran Lingkungan yaitu pencemaran yang disebabkan oleh aktivitas manusia seperti pencemaran yang berasal dari pabrik, kendaraan bermotor, pembakaran sampah, sisa pertanian, dan peristiwa alam seperti kebakaran hutan, letusan gunung api yang mengeluarkan debu, gas, dan awan panas (Roza et al., 2017). Lebih lanjut, substansi tersebut dapat berasal dari sifat alami atau aktivitas manusia maupun campuran diantara keduanya yang dapat berdampak pada kesehatan manusia.

Artikel ini akan menguraikan tentang komposisi dan perilaku gas buangan kendaraan bermotor yang dapat berdampak pada kesehatan manusia.

\section{METODE}

Penelitian ini menggunakan pendekatan kajian teori atau penelitian literer dan bersifat deskriptif eksplorarif, dengan metode deskriptif eksploratif yaitu, pengembangan metode yang mendeskripsikan gagasan-gagasan dalam bentuk naskah primer maupun naskah sekunder untuk kemudian dikembangkan (Lubis, 2019). Fokus pembahasan tentang komposisi gas buangan kendaraan bermotor serta informasi tentang berbagai dampak kesehatan yang ditimbulkan oleh gas buangan kendaraan bermotor. Setelah mendeskripsikan dan membahas selanjutnya ditarik pada satu kesimpulan dan tidak menutup kemugkinan munculnya sebuah penelitian baru.

\section{HASIL DAN PEMBAHASAN}

\section{Komposisi dan perilaku gas buangan bermotor}

Emisi kendaraan bermotor mengandung berbagai senyawa kimia. Komposisi dari kandungan senyawa kimianya tergantung dari kondisi mengemudi, jenis mesin, alat pengendali emisi bahan bakar, suhu operasi dan faktor lain yang semuanya ini membuat pola emisi menjadi rumit (Kusuma et al., 2017). Jenis bahan bakar pencemar yang dikeluarkan oleh mesin dengan bahan bakar bensin maupun bahan bakar solar sebenarnya sama saja, hanya berbeda proporsinya karena perbedaan cara operasi mesin (Muziansyah et al., 2015). Secara visual selalu terlihat asap dari knalpot kendaraan bermotor dengan bahan bakar solar, yang umumnya tidak terlihat pada kendaraan bermotor dengan bahan bakar bensin.

Walaupun gas buang kendaraan bermotor terutama terdiri dari senyawa yang tidak berbahaya seperti nitrogen, karbon dioksida dan upa air, tetapi didalamnya terkandung juga senyawa lain dengan jumlah yang cukup besar yang dapat membahayakan gas buang membahayakan kesehatan maupun lingkungan (Winanda, 2019). Bahan pencemar yang terutama terdapat didalam gas buang buang kendaraan bermotor adalah karbon monoksida (CO), berbagai senyawa hindrokarbon, berbagai oksida nitrogen (NOx) dan sulfur (SOx), dan partikulat debu termasuk timbel (PB) (Buanawati et al., 2017; Haryanto, 2019; Wardoyo, 2016).

Bahan bakar tertentu seperti hidrokarbon dan timbel organik, dilepaskan keudara karena adanya penguapan dari sistem bahan bakar. Lalu lintas kendaraan bermotor, juga dapat meningkatkan kadar partikular debu yang berasal dari permukaan jalan, komponen ban dan rem. Setelah berada di udara, beberapa senyawa yang terkandung dalam gas buang kendaraan bermotor dapat berubah karena terjadinya suatu reaksi, misalnya dengan sinar matahari dan uap air, atau juga antara senyawa-senyawa tersebut satu sama lain. Proses reaksi tersebut ada yang berlangsung cepat dan terjadi saat itu juga di 


\section{Haruna, Pencemaran Udara Akibat Gas Buang Kendaraan}

lingkungan jalan raya, dan adapula yang berlangsung dengan lambat (Heriadi et al., 2015; Inayah, 2016).

Reaksi kimia di atmosfer kadangkala berlangsung dalam suatu rantai reaksi yang panjang dan rumit, dan menghasilkan produk akhir yang dapat lebih aktif atau lebih lemah dibandingkan senyawa aslinya (Haryanto, 2019). Sebagai contoh, adanya reaksi di udara yang mengubah nitrogen monoksida (NO) yang terkandung di dalam gas buang kendaraan bermotor menjadi nitrogen dioksida (NO2 ) yang yang dapat menyebabkan asap awan fotokimi (photochemical smog). Pembentukan smog ini kadang tidak terjadi di tempat asal sumber (kota), tetapi dapat terbentuk di pinggiran kota. Jarak pembentukan smog ini tergantung pada kondisi reaksi dan kecepatan angina (Haryanto, 2019).

Untuk bahan pencemar yang sifatnya lebih stabil seperti limbah $(\mathrm{Pb})$, beberapa hidrokarbonhalogen dan hidrokarbon poliaromatik, dapat jatuh ke tanah bersama air hujan atau mengendap bersama debu, dan mengkontaminasi tanah dan air. Senyawa tersebut selanjutnya juga dapat masuk ke dalam rantai makanan yang pada akhirnya masuk ke dalam tubuh manusia melalui sayuran, susu ternak, dan produk lainnya dari ternak hewan (Hidayat et al., 2016; Nursiah and Haris, 2019; Pertanian, 2018). Karena banyak industri makanan saat ini akan dapat memberikan dampak yang tidak diinginkan pada masyarakat kota maupun desa.

Emisi gas buang kendaraan bermotor juga cenderung membuat kondisi tanah dan air menjadi asam(Amalia, 2017). Pengalaman di negara maju membuktikan bahwa kondisi seperti ini dapat menyebabkan terlepasnya ikatan tanah atau sedimen dengan beberapa mineral/logam, sehingga logam tersebut dapat mencemari lingkungan.

\section{Dampak Terhadap Kesehatan}

Senyawa-senyawa di dalam gas buang terbentuk selama energi diproduksi untuk menjalankan kendaraan bermotor. Beberapa senyawa yang dinyatakan dapat membahayakan kesehatan adalah berbagai oksida sulfur, oksida nitrogen, dan oksida karbon, hidrokarbon, logam berat tertentu dan partikulat. Pembentukan gas buang tersebut terjadi selama pembakaran bahan bakar fosil-bensin dan solar didalam mesin (Zein and Sagaf, 2018). Dibandingkan dengan sumber stasioner seperti industri dan pusat tenaga listrik, jenis proses pembakaran yang terjadi pada mesin kendaraan bermotor tidak sesempurna di dalam industri dan menghasilkan bahan pencemar pada kadar yang lebih tinggi, terutama berbagai senyawa organik dan oksida nitrogen, sulfur dan karbon.

Selain itu gas buang kendaraan bermotor juga langsung masuk ke dalam lingkungan jalan raya yang sering dekat dengan masyarakat, dibandingkan dengan gas buang dari cerobong industri yang tinggi (Busrah et al., 2019). Dengan demikian maka masyarakat yang tinggal atau melakukan kegiatan lainnya di sekitar jalan yang padat lalu lintas kendaraan bermotor dan mereka yang berada di jalan raya seperti para pengendara bermotor, pejalan kaki, dan polisi lalu lintas, penjaja makanan sering kali terpajan oleh bahan pencemar yang kadarnya cukup tinggi. Estimasi dosis pemajanan sangat tergantung kepada tinggi rendahnya pencemar yang dikaitkan dengan kondisi lalu lintas pada saat tertentu .

Keterkaitan antara pencemaran udara di perkotaan dan kemungkinan adanya resiko terhadap kesehatan, baru dibahas pada beberapa dekade belakangan ini. Pengaruh yang merugikan mulai dari meningkatnya kematian akibat adanya episod smog sampai pada gangguan estetika dan kenyamanan. Gangguan kesehatan lain diantara kedua pengaruh yang ekstrim ini, misalnya kanker pada paru-paru atau organ tubuh lainnya, penyakit pada saluran tenggorokan yang bersifat akut maupun khronis, dan kondisi yang diakibatkan karena pengaruh bahan pencemar terhadap organ lain sperti paru, misalnya sistem syaraf (Nasution et al., 2014; Perkotaan and Lubis, n.d.; Suryani, 2010). Karena setiap individu akan terpajan oleh banyak senyawa secara bersamaan, sering kali sangat sulit untuk menentukan senyawa mana atau kombinasi senyawa yang mana yang paling berperan memberikan pengaruh membahayakan terhadap kesehatan.

Bahaya gas buang kendaraan bermotor terhadap kesehatan tergantung dari toksiats (daya racun) masing-masing senyawa dan seberapa luas masyarakat terpajan olehnya (Suryani, 2010). Beberapa faktor yang berperan di dalam ketidakpastian setiap analisis resiko yang dikaitkan dengan gas buang kendaraan bermotor antara lain adalah :

a. Definisi tentang bahaya terhadap kesehatan yang digunakan 
b. Relevansi dan interpretasi hasil studi epidemiologi dan eksperimental

c. Realibilitas dari data pajanan

d. Jumlah manusia yang terpajan

e. Keputusan untuk menentukan kelompok resiko yang mana yang akan dilindungi

f. Interaksi antara berbagai senayawa di dalam gas buang, baik yang sejenis maupun antara yang tidak sejenis

g. Lamanya terpajan (jangka panjang atau pendek)

Pada umumnya istilah dari bahaya terhadap kesehatan yang digunakan adalah pengaruh bahan pencemar yang dapat menyebabkan meningkatnya resiko atau penyakit atau kondisi medik lainnya pada seseorang ataupun kelompok orang. Pengaruh ini tidak dibatasi hanya pada pengaruhnya terhadap penyakit yang dapat dibuktikan secara klinik saja, tetapi juga pada pengaruh yang pada suatu mungkin juga dipengaruhi faktor lainnya seperti umur misalnya. Telah banyak bukti bahwa anak-anak dan para lanjut usia merupakan kelompok yang mempunyai resiko tinggi di dalam peristiwa pencemaran udara. Anak-anak lebih peka terhadap infeksi saluran pernafasan dibandingkan dengan orang dewasa, dan fungsi paru-paru nya juga berbeda. Para usia lanjut masuk di dalam kategori kelompok resiko tinggi karena penyesuaian kapasitas dan fungsi paru- paru menurun, dan pertahanan imunitasnya melemah. Karena kapasitas paru-paru dari penderita penyakit jantung dan paru- paru juga rendah, kelompok ini juga sangat peka terhadap pencemaran udara (Sari, 2018).

Berdasarkan sifat kimia dan perilakunya di lingkungan, dampak bahan pencemar yang terkandung di dalam gas buang kendaraan bermotor digolongkan sebagai berikut :

1. Bahan-bahan pencemar yang terutama mengganggu saluran pernafasan. Yang termasuk dalam golongan ini adalah oksida sulfur, partikulat, oksida nitrogen, ozon dan oksida lainnya (Ulfah, 2018).

2. Bahan-bahan pencemar yang menimbulkan pengaruh racun sistemik, seperti hidrokarbon monoksida dan timbel/timah hitam(Rosianasari, 2016).

3. Bahan-bahan pencemar yang dicurigai menimbulkan kanker seperti hidrokarbon (Edward, 2017).

4. Kondisi yang mengganggu kenyamanan seperti kebisingan, debu jalanan, dll (Arifin, 2019).

\section{SIMPULAN DAN SARAN}

Adapun kesimpulan dari artikel ini bahwa untuk memperoleh kehidupan yang sehat sangat ditentukan oleh lingkungan dimana kita berada serta dorongan dalam diri kita sendiri untuk tetap berperilaku hidup yang sehat. Dorongan untuk berperilaku hidup yang sehat dapat diperoleh melalui pengetahuan dan interaksi dari setiap individu terhadap lingkungannya. Pengetahuan tentang kesehatan akan memberikan kesadaran dan partisipasi bagi setiap orang untuk tetap memelihara dan menjaga dan mempertahankan kondisi lingkungan yang sehat.

Adapun saran dalam mengantisipasi dampak negatif terhadap kesehatan masyarakat khususnya dampak yang ditimbulkan oleh kegiatan industri serta upaya pemerintah dalam mendukung pembangunan berkelanjutan, maka peran pemerintah dalam rnenetapkan beberapa peraturan dan kebijaksanaan di bidang lingkungan hidup sangat dibutuhkan bahwa untuk menjamin pelestarian fungsi lingkungan, setiap usaha atau kegiatan dilarang melanggar baku mutu dan kriteria baku kerusakan lingkungan hidup yang telah ditetapkan oleh pemerintah. 


\section{Haruna, Pencemaran Udara Akibat Gas Buang Kendaraan}

\section{Referensi}

Amalia, R.D., 2017. Strategi Pengendalian Pencemaran Gas CO dari Aktivitas Transportasi di Kota Batu, Jawa Timur (PhD Thesis). Institut Teknologi Sepuluh Nopember.

Arifin, M.S., 2019. Studi Tingkat Kebisingan Lalu Lintas Pada Jalan Tipe 2/2 UD (Studi Kasus: Jalan Pangeran Suryanata Samarinda). KURVA J. Mhs. 1, 1509-1525.

Buanawati, T.T., Huboyo, H.S., Samadikun, B.P., 2017. Estimasi Emisi Pencemar Udara Konvensional (Sox, Nox, Co, dan Pm) Kendaraan Pribadi Berdasarkan Metode International Vehicle Emission (Ive) di Beberapa Ruas Jalan Kota Semarang. J. Tek. Lingkung. 6, 1-12.

Busrah, N.L., Robert, J., Lululangi, M., 2019. Fungsi Ruang Terbuka Hijau (RTH) di Kecamatan Biringkanaya Kota Makassar. UNM Environ. J. 2, 24-27.

Dermawan, 2018. Kajian Strategi Pengelolaan Sampah | Dermawan | UNM Environmental Journals [WWW Document]. URL http://ojs.unm.ac.id/UEJ/article/view/8074 (accessed 7.24.19).

Edward, E., 2017. Pengamatan kadar senyawa polisiklik aromatik hidrokarbon (pah):(benzo [a] pyren, benzo [a] antrasen, Benzo [b] fluoranten, di-benzo [a, h] antrasen, Dan benzo [g, h, i] perylen) dalam air laut di Teluk Jakarta. J. Kelaut. Indones. J. Mar. Sci. Technol. 10, 113-128.

Haryanto, J.T., 2019. Pemetaan Insentif Fiskal Bagi Pengembangan BBM Berkualitas di Indonesia. War. Penelit. Perhub. 27, 311-322.

Heriadi, H., Ismet, F., Fernandez, D., 2015. Pengaruh Pemakaian Koil Tipe Racing Terhadap Konsumsi Bahan Bakar Dan Emisi Gas Buang Pada Sepeda Motor 4 Langkah. Automot. Eng. Educ. J. 1.

Hidayat, N., Sumarsih, S., Putri, A.I., 2016. Mikologi Industri. Universitas Brawijaya Press.

Inayah, S.N., 2016. Studi kandungan pb dan kadar debu pada daun angsana (pterocarpus indicus) dan rumput gajah mini (axonopus. sp) di pusat kota Tangerang.

Kusuma, I.M.W.W., Sukadana, I.G.K., Adnyana, I.W.B., 2017. Kajian Eksperimental Unjuk Kerja Mesin Menggunakan Bahan Bakar Arak Bali. J. Ilm. Tek. DESAIN Mek. Vol 6, 227-231.

Lubis, S., 2019. Tinjauan Normatif Kurikulum Pendidikan Agama Islam Dalam Penanaman Nilai-Nilai Anti-Korupsi. Murabbi 2.

Maulida, A., 2017. Analisis Kegiatan Ekonomi Pemulung Sampah Daur Ulang Di Kelurahan Terjun, Kecamatan Medan Marelan (PhD Thesis). UNIMED.

Muziansyah, D., Sulistyorini, R., Sebayang, S., 2015. Model Emisi Gas Buangan Kendaraan Bermotor Akibat Aktivitas Transportasi (Studi Kasus: Terminal Pasar Bawah Ramayana Koita Bandar. J. Rekayasa Sipil Dan Desain 3, 57-70.

Nasution, A., Siregar, Y.I., Anita, S., 2014. ANALISIS BEBAN PENCEMAR UDARA AMBIEN DARI KEGIATAN TRANSPORTASI DI RUAS JALAN SOEBRANTAS KOTA PEKANBARU.

Nursiah, A., Haris, R., 2019. Perilaku Konsumsi Pangan. UNM Environ. J. 1, 72-76.

K.D.L., LUBIS, E.N., n.d. Permasalahan Pencemaran Udara Karena Emisi Gas Buang Kendaraan Bermotor Dan Dampaknya Terhadap Perkotaan. Kumpul. Makal. 76.

Pertanian, P.P., 2018. Bahaya Kontaminasi Logam Berat Dalam Sayuran dan Alternatif Pencegahan Cemarannya.

Rosianasari, N., 2016. Analisis Karakteristik Emisi CO Dan CO2 Kendaraan Roda Dua di Kampus Fakultas Teknik Universitas Hasanuddin. Makassar Univ. Hasanuddin.

Roza, I.D., Ibrahim, I., Nggeboe, F., 2017. Penerapan Asas Pertanggungjawaban Mutlak (Absolute Liability) Dalam Undang Undang Nomor 32 Tahun 2009 Terhadap Perusakan Dan Pencemaran Lingkungan Di Indonesia. Leg. J. Huk. 1, 132-202.

Sari, N., 2018. Gambaran Paru pada Pekerja Penyapu Jalan di Kota Medan.

Suryani, A.S., 2010. Studi Beban emisi Pencemaran Udara Karbonmonoksida Dari Kendaraan Bermotor di DKI Jakarta. J. Aspir. 1, 75-102.

Ulfah, A.F., 2018. Analisis Konsentrasi NO2, SO2, dan PM10 di Udara Ambien, Sanitasi Rumah, dan Keluhan Gangguan Saluran Pernapasan di wilayah perkebunan PT. Asam Jawa Desa Pangarungan Kecamatan Torgamba Kabupaten Labuhanbatu Selatan Tahun 2017.

Wardoyo, A.Y.P., 2016. Emisi Partikulat Kendaraan Bermotor dan Dampak Kesehatan. Universitas Brawijaya Press.

Winanda, F., 2019. Penggunaan Filter Udara Sebagai Upaya Reduksi Emisi Gas Buang Penyebab Pemanasan Global.

Zein, K., Sagaf, S., 2018. Analisis Paparan Kebisingan Pesawat Terbang di Bandara Babullah Ternate. UNM Environ. J. 1, 39-44. 